\title{
BEHAVIOR OF HELICAL PILES - AS A GEOENVIRONMENTAL CHOICE - - BY FRUSTUM CONFINING VESSEL
}

\author{
Javad Khazaie', Abolfazl Eslami' ${ }^{1}$ \\ 1 Department of Civil and Environmental Engineering, Amirkabir University of Technology (AUT), Tehran, \\ Islamic Republic of Iran, e-mail: javad_khazaei@aut.ac.ir, afeslami@aut.ac.ir
}

Received: 2016.05.06

Accepted: 2016.07.07

Published: 2016.09.01

\begin{abstract}
Helical piles are environmentally friendly and economical deep foundations that, due to environmental considerations, are excellent additions to a variety of deep foundation alternatives available to the practitioner. Helical piles performance depends on soil properties, the pile geometry and soil-pile interaction. Helical piles can be a proper alternative in sensitive environmental sites if their bearing capacity is sufficient to support applied loads. The failure capacity of helical piles in this study was measured via an experimental research program that was carried out by Frustum Confining Vessel (FCV). FCV is a frustum chamber by approximately linear increase in vertical and lateral stresses along depth from top to bottom. Due to special geometry and applied bottom pressure, this apparatus is a proper choice to test small model piles which can simulate field stress conditions. Small scale helical piles are made with either single helix or more helixes and installed in fine grained sand with three various densities. Axial loading tests including compression and tension tests were performed to achieve pile ultimate capacity. The results indicate the helical piles behavior depends essentially on pile geometric characteristics, i.e. helix configuration and soil properties. According to the achievements, axial uplift capacity of helical model piles is about equal to usual steel model piles that have the helixes diameter. Helical pile compression bearing capacity is too sufficient to act as a medium pile, thus it can be substituted other piles in special geoenvironmental conditions. The bearing capacity also depends on spacing ratio, $\mathrm{S} / \mathrm{D}$, and helixes diameter.
\end{abstract}

Keywords: helical pile, environment, geoenvironment, frustum confining vessel, physical modeling, bearing capacity.

\section{INTRODUCTION}

Many researches have been performed to find a suitable type of piles for various geotechnical and structural conditions. Firstly, the pile shape was a simple shaft, then developed to complex forms over time similar to these currently used, including Omega piles, Franki piles, Atlas piles, Fundex piles, cast flight auger (CFA) piles, screw piles, helical piles and etc [1]. So, environmental considerations have no share in these studies. In recent decades environmental considerations have been very important, so nowadays all constructions must been studied either technical or environmental. Helical piles are steel deep foundations that are made from some sections as indicated in Figure 1a. The figure shows that a helical pile includes the lead, extensions, helical bearing plates, and pile cap (In some helical piles there is no part as a pile cap). These piles are rotated into the ground to bear lateral, axial tensile and compressive loads. The lead section is the first section to enter the ground. It has a tapered pilot point and typically one or multiple helical bearing plates. Extension sections are used to advance the lead section deeper into the ground until the desired bearing stratum is reached. Extension sections can have additional helical bearing plates 


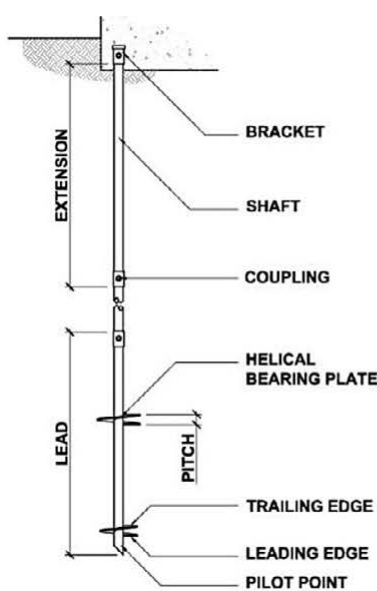

a

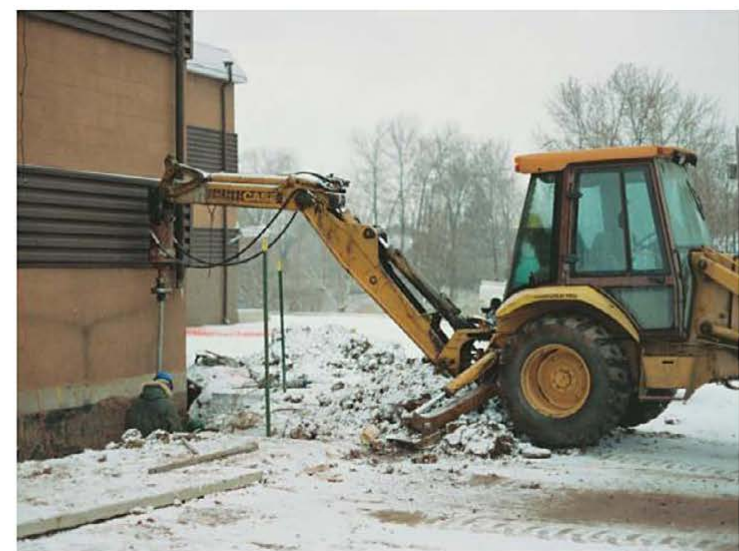

b

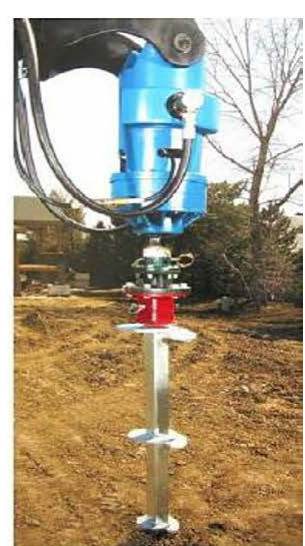

c

Fig 1. a) Schematic of helical piles; b) Installation as building support [5], c) helical pile during installation [5]

but often are comprised of a central shaft and couplings only. The couplings generally consist of bolted male and female sleeves. The central shaft is commonly a solid square bar or a hollow tubular round section [2]. Helical piles and anchors have been used to support boardwalks in environmentally sensitive areas, to support tower foundations (new and retrofit), to support and lift existing structures, to augment existing foundations, soil nailing applications, heavily loaded piles in new construction, and retaining wall support and tiebacks (new and retrofit) [3]. Recently, helical piles have been used as deep foundations to bear both compression and uplift loads up to $3000 \mathrm{KN}$ and can be used as a deep foundation in usual structures [4]. Although helical piles have been used as supports and anchors for a long time, there is little information available on their performance in compare to other piling industry; they are not well-known to be used commonly. Therefore, it is required to run more study on characteristics and compile records of helical piles behavior and performance.

A helical pile is defined as a foundation element consisting of a central shaft with at least one helix or more helixes plates located on the shaft with its axis positioned parallel to the shaft's length [6].

The shaft shape can be square or circular and its diameter is not a constant or normal diameter, recorded data in various studies indicated it varies between 50 to $965 \mathrm{~mm}$, while helix diameter varies between 150 to $1219 \mathrm{~mm}[2,4]$.

According to Kurian and Shah (2009) the helical pile is an old type of foundation which has staged a comeback recently and becom- ing common more and more and is used in a variety of situations. [7] However, Perko and Darin Willis (2009) have regarded some exceptions that in the past helical piles were barely mentioned in undergraduate and graduate civil engineering studies. They were considered an alternative in a way that geotechnical engineers would take it into consideration in some special cases. Recently, helical piles are widely known by most practicing engineers and can be used as an essential part of deep foundations [8,9]. Now, there are over 50 helical pile manufacturing companies in at least twelve countries and there may be more than 2,000 helical pile installation contractors in the United States alone [8]. Helical pile installation by a torque motor is indicated in Figure 1b, 1c [9].

\section{HELICAL PILES AND THE ENVIRONMENT}

Helical piles have environmental advantages that make them considerable for geotechnical and practicing engineers. A helical pile foundation construction expends less raw material and, as seen in Table 1, requires fewer truck trips compared to other types of deep foundations, Fewer truck trips mean less traffic, less pollution, and less wear-and-tear on roads, streets, and highways. On the other hand, because of their light weight, helical piles application reduces the carbon footprint. According to Perko studies, the construction of helical piles requires on the order of 65 percent less raw materials by weight to construct compared to driven steel piles and 95 percent less raw material by weight compared to drilled shafts or auger cast piles 
Table 1. Required Truck Trips for various piles [2]

\begin{tabular}{|c|c|c|}
\hline Foundation option & Number of trips foundation option to/from site & Trip description \\
\hline 50 helical piles & $\begin{array}{l}1 \\
2 \\
3\end{array}$ & $\begin{array}{l}\text { truck \& trailer (installation machine) } \\
\text { flatbed tractor-trailers (helical piles) }\end{array}$ \\
\hline 50 drilled shafts & $\begin{array}{c}14 \\
1 \\
1 \\
1 \\
17\end{array}$ & $\begin{array}{c}\text { concrete trucks } \\
\text { pump truck } \\
\text { flatbed tractor trailer (reinforcing steel) } \\
\text { drill rig }\end{array}$ \\
\hline 50 driven $\mathrm{H}$-piles & $\begin{array}{l}2 \\
4 \\
1 \\
7\end{array}$ & $\begin{array}{c}\text { crane delivery \& pickup } \\
\text { flatbed tractor trailers (H-Piles) } \\
\text { pile-driving rig }\end{array}$ \\
\hline
\end{tabular}

[2]. So, helical piles reduce the overall carbon footprint of a project in many ways (production, mobilization and installation).

Ease of installation and require to smaller installation machines with better fuel economy in a shorter time period, is an environmental advantage that make helical piles better to use. In a project concrete omission reduces pollution because the production of cement is one of the leading producers of carbon emissions. Perko (2008) presented a project properties that was determined that shipping approximately 350 helical piles from Cincinnati, Ohio, to Denver, Colorado, consumed on the order of 40 percent less fuel than would be required to transport concrete and reinforcing steel from local suppliers to the site for the construction of a drilled shaft foundation with equivalent capacity and performance [2].

In some projects that are located in environmentally sensitive areas, such as wetlands, prairies, or historical sites, lightweight installation equipment minimizes disturbance, reduces installation noises and impact or vibration. Also, by possibility of helical piles installing in frozen sites, constructions can be done during the winter. Overall, helical piles may be one of the most environmentally friendly deep foundation systems. As presented above, helical piles are a proper alternative in where the environment is sensitive. These piles will be the best choice if compressive, tensile and lateral loads can be beard by them.

In this study it is tried to investigate helical piles performance in conparison with usual piles by physical modeling named FCV.

\section{BACKGROUND ON BEARING CAPACITY}

Several investigations have been done to determine helical pile bearing capacity. It is tried to find relationships between bearing capacity and torque installation, helix diameter, helixes depth and the spacing ratio. Various numerical analyses also were carried out to investigate the capacity of helical piles under axial loads. For example $\mathrm{He}$ Liu et al (2007) reported an equation, based on their Finite-Element analysis in frozen ground, that the helix capacity is determined by calculating the soil's unit-bearing capacity and applying it to the individual helix areas. In this theory, the helixes should be spaced far enough apart [11].

$$
\mathrm{Q}_{\mathrm{t}}=\sum \mathrm{Q}_{\mathrm{h}}
$$

where: $\mathrm{Q}_{\mathrm{t}}$ - helical pile capacity,

$\mathrm{Q}_{\mathrm{h}}$ - individual helix bearing capacity resulted from Equation 3.

$$
\mathrm{Q}_{\mathrm{h}}=\mathrm{A}_{\mathrm{h}}\left(9 \mathrm{C}+\mathrm{qN}_{\mathrm{q}}\right)<\mathrm{Q}_{\mathrm{s}}
$$

where: $\mathrm{A}_{\mathrm{b}}$ - projected helix area,

$\mathrm{C}$ - soil cohesion,

q - effective overburden pressure,

$\mathrm{N}_{\mathrm{q}}$ - bearing capacity factor,

$\mathrm{Q}_{\mathrm{s}}^{\mathrm{q}}$ - upper limit determined by pile material strength.

The axial capacity of helical piles depends mainly on soil type and spacing ratio (S/D), where $S$ and $D$ are the average spacing and diameter of helixes, respectively [12]. Failure can either occur at each individual helix (Fig. 2a) or in cylindrical shear surface (Fig. 2b). In the first state, total capacity of helical pile in compression or tension is the sum of the capacities of the individual helixes plus shaft resistance, (Meyer- 


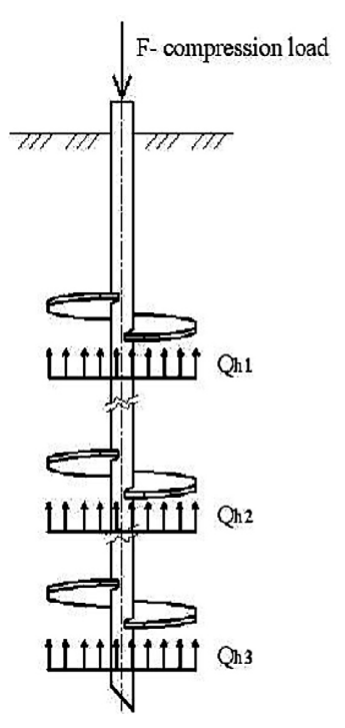

a

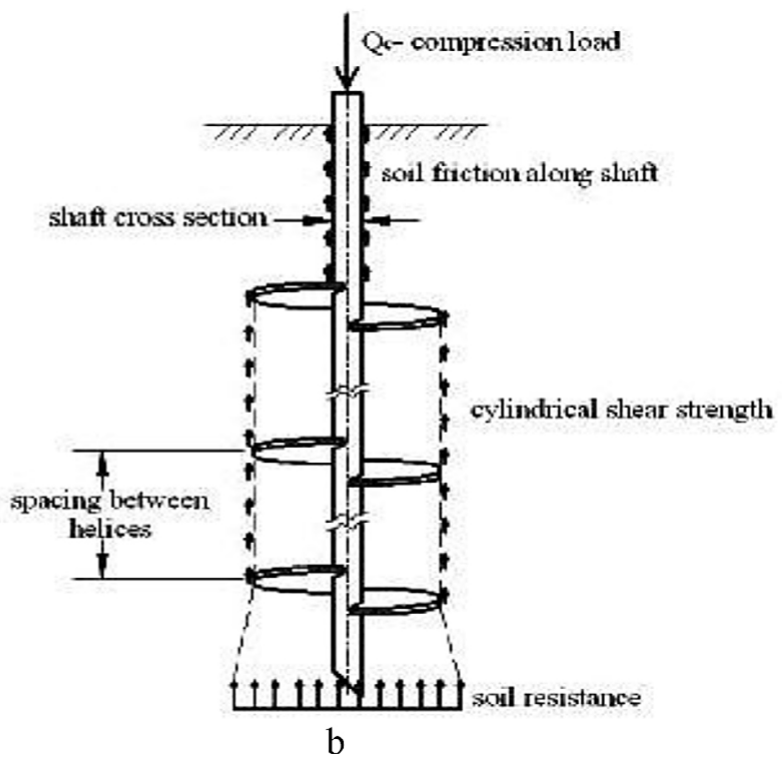

Fig. 2. Two common models for estimating helical pile axial capacity: a) individual helix method, b) cylindrical shear method [13]

hof and Adams (1968), Vesic (1971), Canadian Geotechnical Society (2006)). In the second state a cylindrical shear failure surface is formed with the connecting uppermost to lowermost helixes, as shown in Fig. 2b. Hence, the axial capacity is derived mainly from the shear resistance along the cylindrical surface and bearing resistance above the top helix for uplift loading. In compression loading the axial capacity is derived from the bearing resistance below the bottom helix and the shear resistance along the cylindrical surface as mentioned above (Vesic (1971), Mitsch and Clemence (1985), Das (1990), Zhang (1999)) [12-14].

Sakr (2009) also reported bearing capacity equations of helical piles from Canadian Foundation Engineering Manual (CFEM, 2006). As suggested in that manual, the following equation is given for the bearing capacity of helical piles $[13,14]$ :

$$
\mathrm{Q}_{\mathrm{u}}=\mathrm{Q}_{\mathrm{h}}+\mathrm{Q}_{\mathrm{f}}
$$

where: $\mathrm{Q}_{\mathrm{u}}$ - ultimate pile capacity,

$\mathrm{Q}_{\mathrm{h}}$ - individual helix bearing capacity,

$\mathrm{Q}_{\mathrm{f}}$ - shaft resistance.

The individual helix bearing capacity can be computed from Eq. 4:

$$
\mathrm{Q}_{\mathrm{u}}=\mathrm{A}_{\mathrm{h}}\left(\mathrm{S}_{\mathrm{u}} \mathrm{N}_{\mathrm{c}}+\gamma \mathrm{D}_{\mathrm{h}} \mathrm{N}_{\mathrm{q}}+\gamma \mathrm{DN}_{\gamma}\right)
$$

where: $A_{h}$ - the helix area,

$\mathrm{S}_{\mathrm{u}}$ - the undrained shear strength of the soil,

$\gamma-$ the unit weight of the soil,

$\mathrm{D}_{\mathrm{h}}$ - the bearing helix depth,

$\mathrm{D}$ - the helix diameter,
$\mathrm{N}_{\mathrm{c}}, \mathrm{N}_{\mathrm{q}}$ and $\mathrm{N}_{\gamma}$ - bearing capacity factors for local shear conditions.

In continuation of Canadian Foundation Engineering Manual (CFEM, 2006), the shaft resistance, $\mathrm{Q}_{\mathrm{f}}$ is resulted from Eq. 5:

$$
\mathrm{Q}_{\mathrm{f}}=\sum \pi \mathrm{d} \Delta \mathrm{L}_{\mathrm{i}} \mathrm{q}_{\mathrm{si}}
$$

where: $\mathrm{d}$ - the shaft diameter,

$\Delta \mathrm{L}_{\mathrm{i}}$ - the pile segment length in soil layer $\mathrm{i}$,

$\mathrm{q}_{\mathrm{si}}$ - the average unit shaft friction of soil layer $\mathrm{i}$.

Values of $\mathrm{d}$ and $\Delta \mathrm{L}_{\mathrm{i}}$ can be measured directly and $\mathrm{q}_{\mathrm{si}}$ can be estimated from following expression:

$$
\mathrm{q}_{\mathrm{si}}=\sigma_{\mathrm{v}} \mathrm{K}_{\mathrm{s}} \tan \delta
$$

where: $\sigma_{v}^{\prime}$ - the vertical effective stress at the middepth of each soil layer,

$\mathrm{K}_{\mathrm{s}}$ - the coefficient of lateral earth pressure, $\delta$ - the interface friction angle.

$\mathrm{K}_{\mathrm{s}}$ value depends on friction angle, $\varphi$, and is determined by $\mathrm{K}_{\mathrm{s}}=2(1-\sin \varphi)$ for driven piles [12].

At the time being, almost all researchers have expressed that helical pile bearing capacity can be computed by the equation 8 as follows [13]:

$$
\mathrm{Q}_{\mathrm{c}}=\left(\mathrm{Q}_{\mathrm{hf}}+\mathrm{Q}_{\mathrm{hb}}\right)+\mathrm{Q}_{\mathrm{s}}
$$

The major problem in various methods are estimating $\mathrm{Q}_{\mathrm{hf}}$ (helix friction), $\mathrm{Q}_{\mathrm{hb}}$ (helix bearing) and $Q_{s}$ (shaft friction). Hence, the effect of pile configuration variances on capacity bearing is the most important subject that several studies have been carried out on it. Kurian and Shah (2009) 
have done a numerical study by finite element method on helical piles. They compared helical pile performance with that of prismatic piles. In that study the finite element analysis is eminently suited for analyzing helical piles as it can incorporate the geometrical details of the helical blades at the micro level. They presented in a quantitative form, the bearing capacity increases with increasing the helix diameter. Moreover, when the helix surface varies from smooth to rough, an increase is also reported [7].

Sprince and Pakrastinsh (2010) reported a considerable increasing in pile capacity when helix diameter and its depth increases, [15].

Di Bernardo (2012) carried out a field test program in various soils between years 2009 to 2012 and indicated that helical piles can be used not only in fine grained deposits but also in all soil types even frozen areas and rocky sites [16].

Sakr (2011) reported that uplift capacity of helical piles is about $80 \%$ of compressive capacity $[3,6]$. but, Livneh and El Naggar (2008) had reported fewer values of uplift capacities. They proposed a failure criterion to predict the ultimate load for the helical piles. The ultimate load is defined as the load associated with deflection equal to $8 \%$ of the diameter of the largest helix plus the elastic deflection of the pile [17].

\section{PHYSICAL MODELING FOR STUDYING HELICAL PILE PERFORMANCE}

Physical modeling has been recognized as a proper tool to study the pile behavior. It has an important advantage that allows one to carry out many tests that are not expensive in comparison to field programs. In this approach, pile testing is not difficult in various soil types. In fact, physical modeling offers the possibility of studying both theoretical and practical viewpoints $[18,19]$.

Common small scale sets including simple chambers $(1 \mathrm{~g})$, calibration chambers (CC), and centrifuge apparatus (ng), have some limitations and difficulties. For instance a limitation of simple chambers is low stress level in compare to real condition surrounding pile in the field. A major limitation of the calibration chambers is uniformity of lateral stresses in all over the chamber and centrifuge apparatus tests are so complex and costly [19].

In recent years, Frustum Confining Vessels (FCV) have been developed for physical modeling of penetrometers and piles. This device is a truncated cone shape that applies a steady pressure on its bottom, so a linear stress distribution is created along its vertical central core. This specification can be the most important advantage of Frustum Confining Vessels (FCV), because it simulates field real overburden and lateral stress conditions. The vertical stress in the soil at the top is zero and it increases with depth to the stress value that applied in the bottom by pressure system. Several model piles in various void ratios and base pressures were tested via FCV by Horvath and stole (1996) and it has been illustrated that there is a linear stress distribution via depth in FCV $[18,20]$. Figure 3 a show schematic form of the first FCV having been built in McMaster University. Stress distribution along vertical center line of FCV has been drawn in Figure 3b.

Scaling factors using for FCV can be calculated by simulation theories, depending on the degree

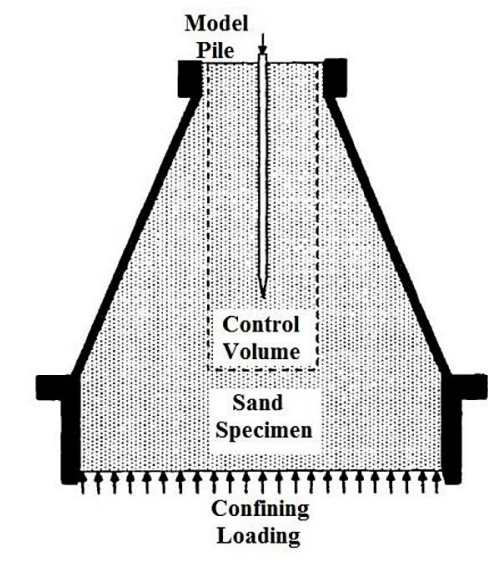

a

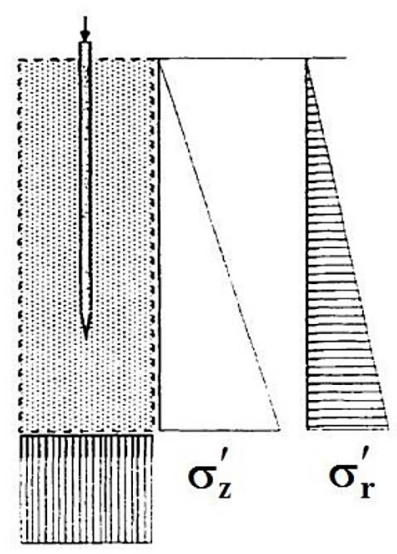

b

Fig. 3. a) Schematic of the FCV, b) Idealized distribution of stresses within control volume [17] 


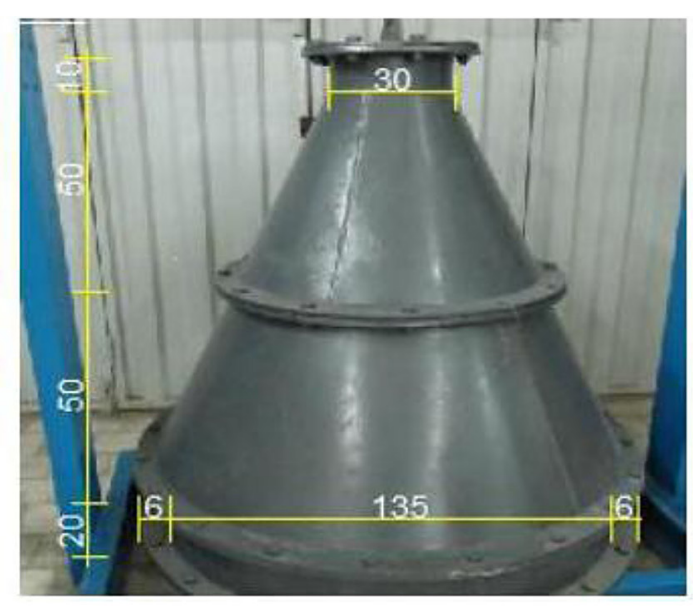

(a)

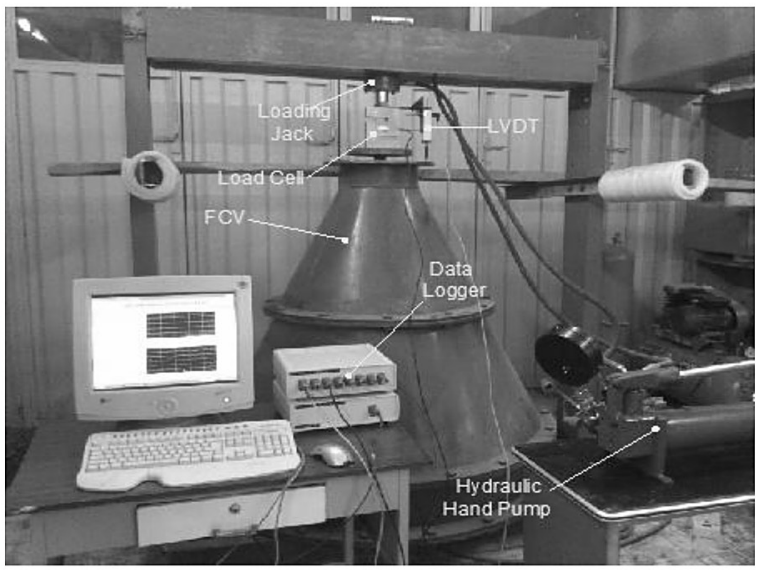

(b)

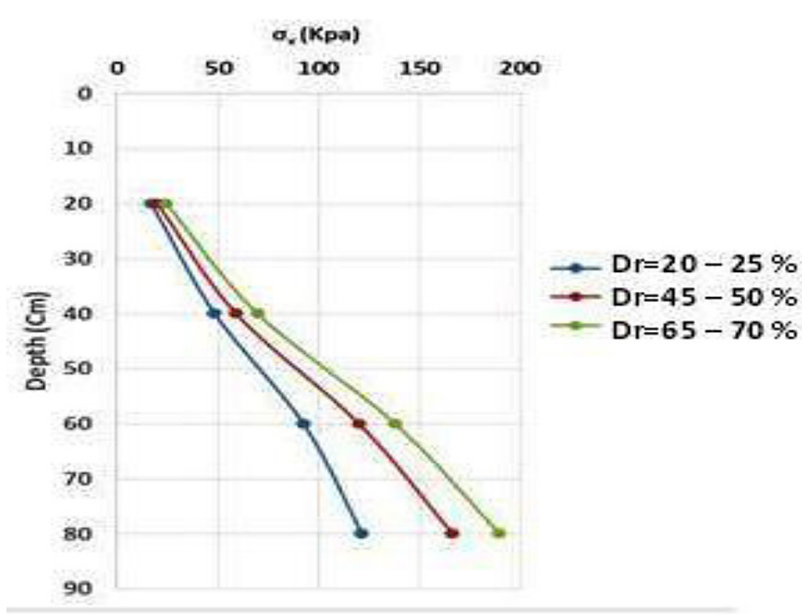

(c)

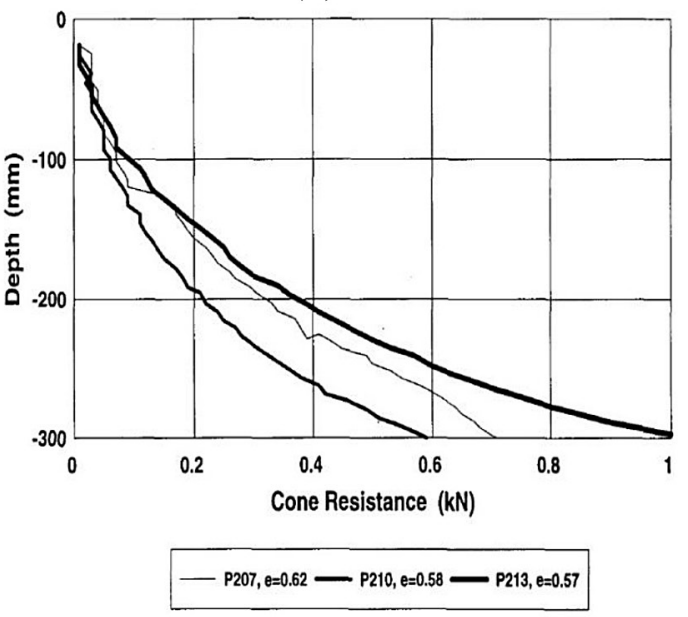

(d)

Fig. 4. a) FCV-AUT and its dimensions (cm), b) Overview of FCV at AUT and its accessories [19], c)Stress distribution in FCV-AUT by Zare and Eslami [19], d) Lateral stress distribution in FCV by Sedran [18]

to which it is pressurized. Sedran (1999) reported the factors relevant to FCV in his research [18].

The FCV used in the current study has been built in AmirKabir University of Technology (AUT) by Zare and Eslami in 2011 named FCVAUT. It has a height of $1200 \mathrm{~mm}$, with top and bottom diameters of 300 and $1350 \mathrm{~mm}$, respectively (Fig. 4a). Through the application of bottom pressure range from 100 to $400 \mathrm{kPa}$, the in-situ overburden stress conditions equivalent up 10 to $40 \mathrm{~m}$ soil deposits almost consistent to the embedment depth of commonly used piles. Axial compression and tension tests focusing on load-movement behavior were conducted to evaluate the performance of the FCV for model piles. Tested model piles confirmed that there is approximately a linear trend of stress distribution and this device can create realistically overburden stress in the desired control volume along the central core [19].

Sedran (1999) demonstrated that stress dis- tributions along the centerline obtained by membrane loading were smoother than in the case of piston loading. Hence, in the AUT- FCV, a membrane to apply bottom pressure has been installed. This device consists of four major parts such as the frustum body, bottom pressure system, loading system (loading frame, hydraulic hand pump and hydraulic jack) and instrumentation system. Hydraulic jack designed and made to apply tension and pressure load. Maximum load is 15 tons and maximum displacement is $150 \mathrm{~mm}$. The power of jack, which is designed to apply hydraulic pressure up to 300 bars, is provided by a hydraulic hand pump with a switch valve.

Instrumentation system includes Data Acquisition System (DAS) and sensors. DAS includes an 8-channel data logger, power pack and a computer. Sensors include a 10-ton S-shape load cell, an LVDT with $50 \mathrm{~mm}$ courses and five soil pressure cells with $1000 \mathrm{kPa}$ capacity. 


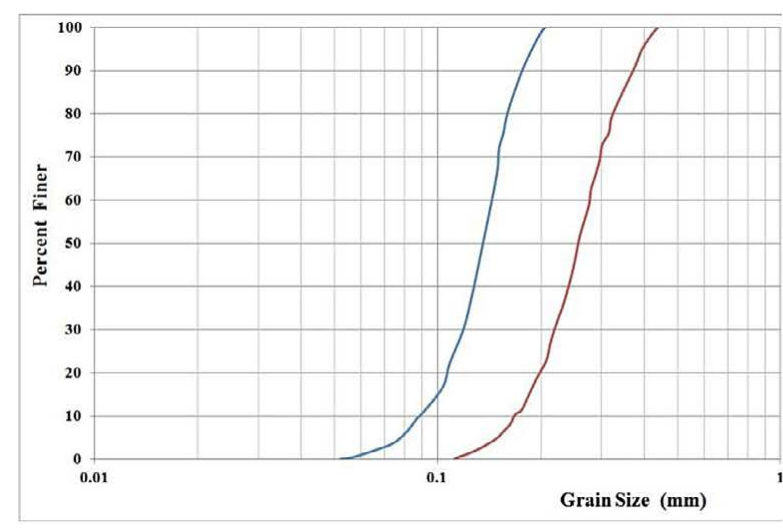

a

\begin{tabular}{c|c|c|c|c}
\hline $\begin{array}{c}\text { Relative } \\
\text { density } \\
\left(\mathrm{D}_{\mathrm{r}}\right) \%\end{array}$ & $\begin{array}{c}\gamma_{d(\min )} \\
\left(\mathrm{kN} / \mathrm{m}^{3}\right)\end{array}$ & $\begin{array}{c}\gamma_{d(\max )} \\
\left(\mathrm{kN} / \mathrm{m}^{3}\right)\end{array}$ & $\begin{array}{c}\text { Cohesion } \\
(\mathrm{kPa})\end{array}$ & $\begin{array}{c}\text { Internal } \\
\text { Friction Angle }\end{array}$ \\
\hline $25-30$ & 14.85 & 17.99 & 1 & 29.9 \\
\hline $45-50$ & 14.85 & 17.99 & 2 & 32.2 \\
\hline $65-70$ & 14.85 & 17.99 & 2 & 35 \\
\hline
\end{tabular}

\section{EXPERIMENTAL STUDY BY FCV-AUT}

Babolsar is a coastal city in northern area of Mazandaran province in Iran. In this experimental study Babolsar sand was used as geomaterial and surrounding soil of model piles. The sand was approximately uniform soil and has a grain size distribution curve as shown in Fig. 5a. So, the sand is categorized as SP in Unified Soil Classification System (USCS). The sand properties due to laboratory tests are given in Fig. 5 b.

For testing, first the sand prepared and placed in FCV-AUT in loose state by air raining method and leveled by a wooden pallet in each $50 \mathrm{~mm}$ depth. In this filling method relative density is about $20 \%$ to $25 \%$. In the second state, which relative density is about $45 \%$ to $50 \%$, the sand placed in FCV and each $50 \mathrm{~mm}$ layers height compacted by body vibration. Hammer compaction in layers is used to achieve $65 \%$ to $70 \%$ relative density.

The tests were applied on short rigid model piles in vertical compressive and pullout tests in the FCV-AUT. As indicated in Table 2, all fourteen model piles tested in this study have 750 $\mathrm{mm}$ embedment depth and were made from 4 $\mathrm{mm}$ thick steel plate. Shaft diameters of three usual and eleven helical model piles are $89 \mathrm{~mm}$ and $32 \mathrm{~mm}$, respectively. Helix diameters vary from 64 to $89 \mathrm{~mm}$ and spacing ratios are assumed 1 to 5 . Some model piles are shown in Fig. 6.

Common piles include open and close end models were driven vertically by hammer knocking and Jacking, the jacking pile was an open

Table 2. Model piles characteristics

\begin{tabular}{|c|c|c|c|c|c|c|c|c|}
\hline $\begin{array}{l}\text { Length } \\
(\mathrm{mm})\end{array}$ & $\begin{array}{l}\text { Thickness } \\
\text { (mm) }\end{array}$ & \multicolumn{2}{|c|}{$\begin{array}{l}\text { Average diameter } \\
(\mathrm{mm})\end{array}$} & $\begin{array}{l}\text { Installation } \\
\text { method }\end{array}$ & \multicolumn{3}{|c|}{ Pile type } & $\begin{array}{l}\text { Model } \\
\text { number }\end{array}$ \\
\hline 750 & 4 & \multicolumn{2}{|c|}{89} & jacking & \multicolumn{3}{|c|}{ open end } & 1 \\
\hline 750 & 4 & \multicolumn{2}{|c|}{89} & hammer knocking & \multicolumn{3}{|c|}{ close end } & 2 \\
\hline 750 & 4 & \multicolumn{2}{|c|}{89} & hammer knocking & \multicolumn{3}{|c|}{ open end } & 3 \\
\hline 750 & 4 & helix diameter & $\begin{array}{c}\text { shaft } \\
\text { diameter }\end{array}$ & torque motor & $\begin{array}{l}\text { spacing ratio } \\
\text { (S/D) }\end{array}$ & helixes & \multirow{12}{*}{$\begin{array}{l}\text { helical } \\
\text { piles }\end{array}$} & \\
\hline 750 & 4 & $64 \mathrm{~mm}$ & $32 \mathrm{~mm}$ & torque motor & - & 1 & & 4 \\
\hline 750 & 4 & 89 mm & $32 \mathrm{~mm}$ & torque motor & - & 1 & & 5 \\
\hline 750 & 4 & 89 mm & 32 mm & torque motor & 1 & 2 & & 6 \\
\hline 750 & 4 & 89 mm & $32 \mathrm{~mm}$ & torque motor & 2 & 2 & & 7 \\
\hline 750 & 4 & 89 mm & $32 \mathrm{~mm}$ & torque motor & 3 & 2 & & 8 \\
\hline 750 & 4 & 89 mm & $32 \mathrm{~mm}$ & torque motor & 4 & 2 & & 9 \\
\hline 750 & 4 & 89 mm & $32 \mathrm{~mm}$ & torque motor & 5 & 2 & & 10 \\
\hline 750 & 4 & $64,89 \mathrm{~mm}$ & $32 \mathrm{~mm}$ & torque motor & 3 & 2 & & 11 \\
\hline 750 & 4 & $89,64 \mathrm{~mm}$ & $32 \mathrm{~mm}$ & torque motor & 3 & 2 & & 12 \\
\hline 750 & 4 & 89 mm & $32 \mathrm{~mm}$ & torque motor & $2-3$ & 3 & & 13 \\
\hline 750 & 4 & 89 mm & 32 mm & torque motor & $3-2$ & 3 & & 14 \\
\hline
\end{tabular}




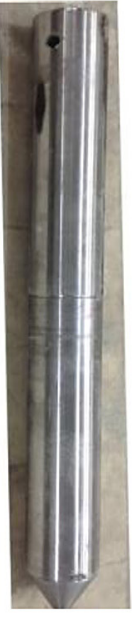

a

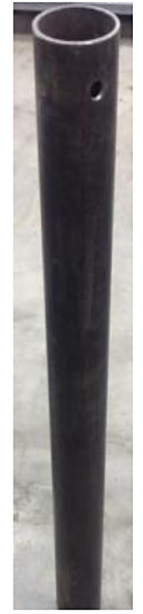

b

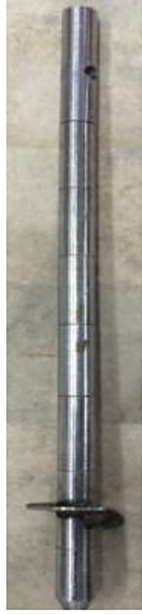

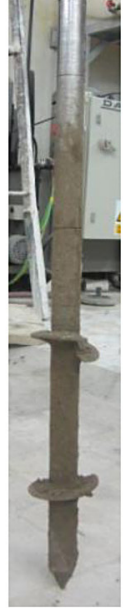

d

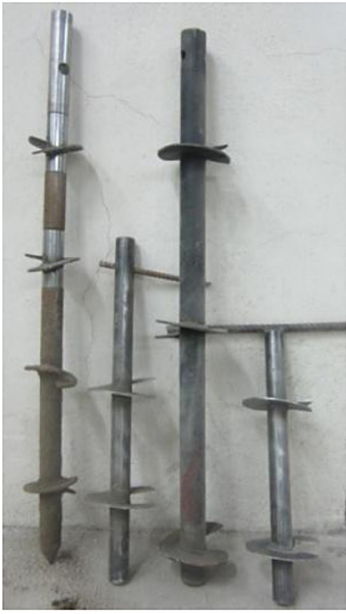

e

Fig. 6. a) steel pile, b) open ended steel pile, c) single helix pile, d) double helixes pile, e) multi helixes piles

end model. The helical model piles were driven by torque implementation. All compressive and tensile loading tests were carried out on every model pile. The vertical load was applied in a stepwise manner by a hydraulic system. A load cell and linear vertical displacement transducers (LVDT) with high precision of $0.001 \mathrm{~mm}$ were mounted on the loading piston to measure the total vertical imposed loads and corresponding displacement of pile head (Fig. 7). After driving pile, FCV-AUT base pressure up to $200 \mathrm{kPa}$ was applied. The loading starts and continued till the pile head displacement goes up and reaches $30 \%$ pile diameter as indicated in Figures 8-16.

There are a few number of failure criteria used to interpret the axial compressive capacities of piles from pile load test results such as the Davisson criterion, Brinch Hansen, L1-L2 method, and FHWA (5\%) criteria [21]. It should be pointed out in many situations the design of foundations is controlled by the allowable structural displacements at foundation level [21]. In experimental studies the head pile displacement which pile capacity is measured, varies between 5 to $30 \%$ of average pile diameter. Therefore, pile loading is continued to $30 \%$ for a detailed study in the present study but the major criterion was focused less than $15 \%$ of the average pile diameter.

\section{RESULTS AND DISCUSSION}

As explained, fourteen model piles (small scale) were tested by FCV-AUT in this study. The base pressure applying system pressurized on 200 $\mathrm{kPa}$. It simulates a full scale pile with about 10 to $15 \mathrm{~m}$ embedment depth in Babolsar sand. The

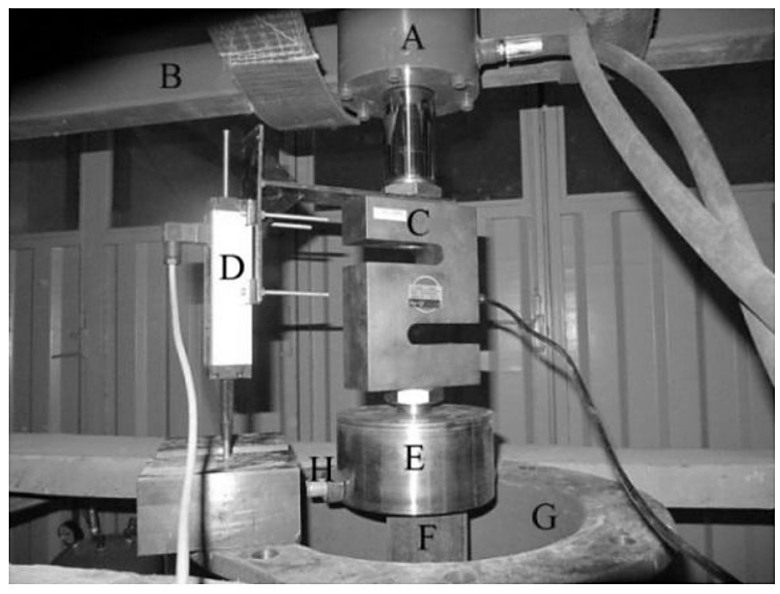

a

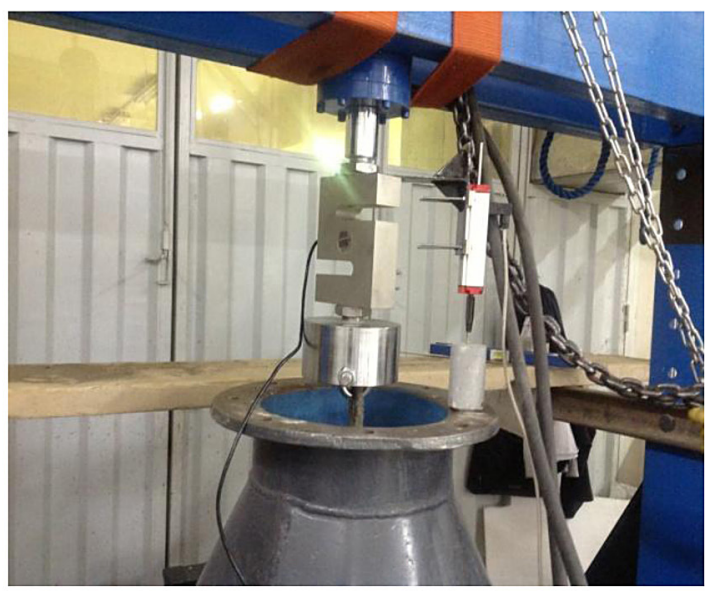

b

Fig. 7. a) AUT-FCV Loading system, A: Hydraulic Jack, B: Reaction beam, C: Load Cell, D: LVDT, E: Loading cap, F: Model Pile, G: FCV [18], b) Tensile test by FCV 
rate of pile loading was set in such a manner that in each loading step, pile head displacement approximately be fixed. The penetration was about $2.5 \mathrm{kN}$ in each 2 minutes, i.e. $20 \mathrm{~N} / \mathrm{sec}$.

This study was performed to investigate geotechnical model piles behavior. Hence, in all model piles the effect of soil densification and also difference in compression and tension were studied, effect of spacing ratio, size and number of helixes were studied only in helical models.

The test results are presented as load-displacement curves. It is important to be ensured that the results would be acceptable; therefore, this criterion, i.e. repeatability was examined by primary tests which are presented in Figure 8. The result resemblance in that figure either helical models demonstrates that FCV results are repeatable and reliable.

As expressed before, criterion load was based on corresponding load with head pile displace- ment of $15 \%$ of pile diameter. Due to this norm, the maximum of compression applied loads in open-end model piles varied between 9.4 to 50 $\mathrm{kN}$ for loose to dense sands while, the head pile displacements up to $15 \%$ of pile average diameter (Fig. 9a). The maximum of tension applied loads also are about 1.3 to $14 \mathrm{kN}$ (Fig. 9b). Results of close-end models indicated in Fig. 10 show that this model pile can bear 11 to $65 \mathrm{kN}$ compressive loads and 2.2 to $14 \mathrm{kN}$ tensile loads. In addition, compression and tension capacity of open end models were installed by jacking, varied from 16 to $89 \mathrm{kN}$ and 1.5 to $14.3 \mathrm{kN}$, respectively as shown in Figure 11.

For these model piles, there is a low applied compressive load growth after displacement of $10 \%$ pile diameter and also a low growth in tensile load after displacement of 5\% pile diameter. So, the criterion of displacement $15 \%$ can be reasonably accepted from the viewpoint of ultimate pile
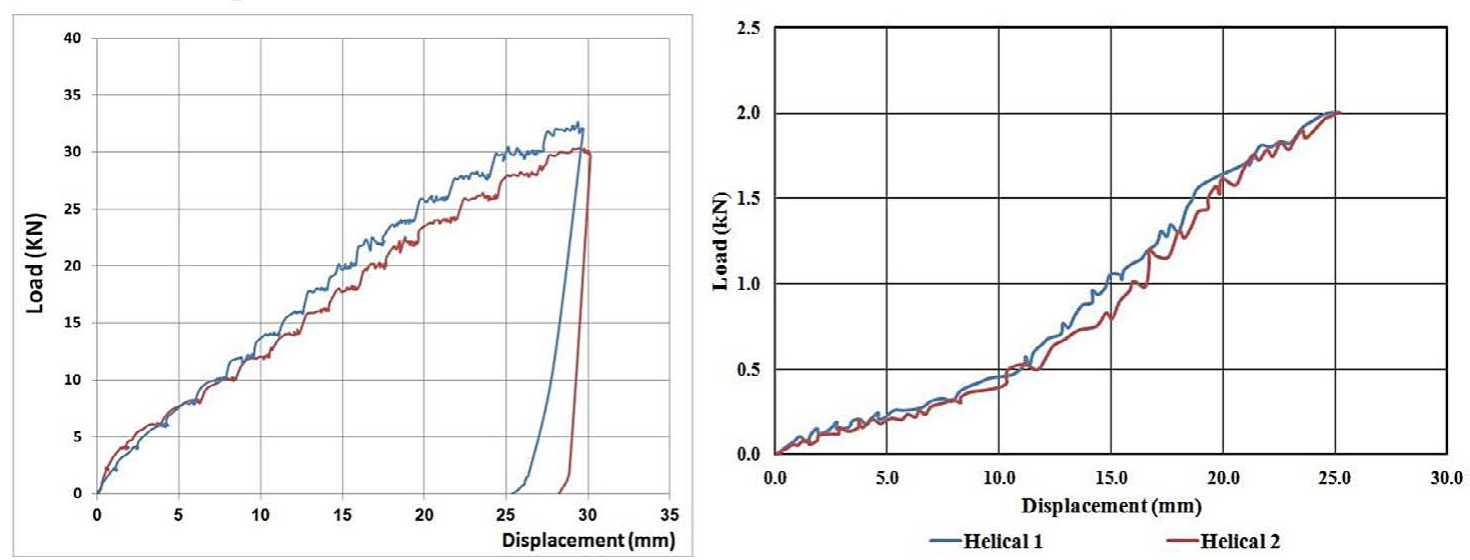

Fig. 8. Load-Displacement curve in FCV-AUT for indicating test repeatability: Left) Helical model piles in compression, Right) single helical model piles in tension (500 mm length)
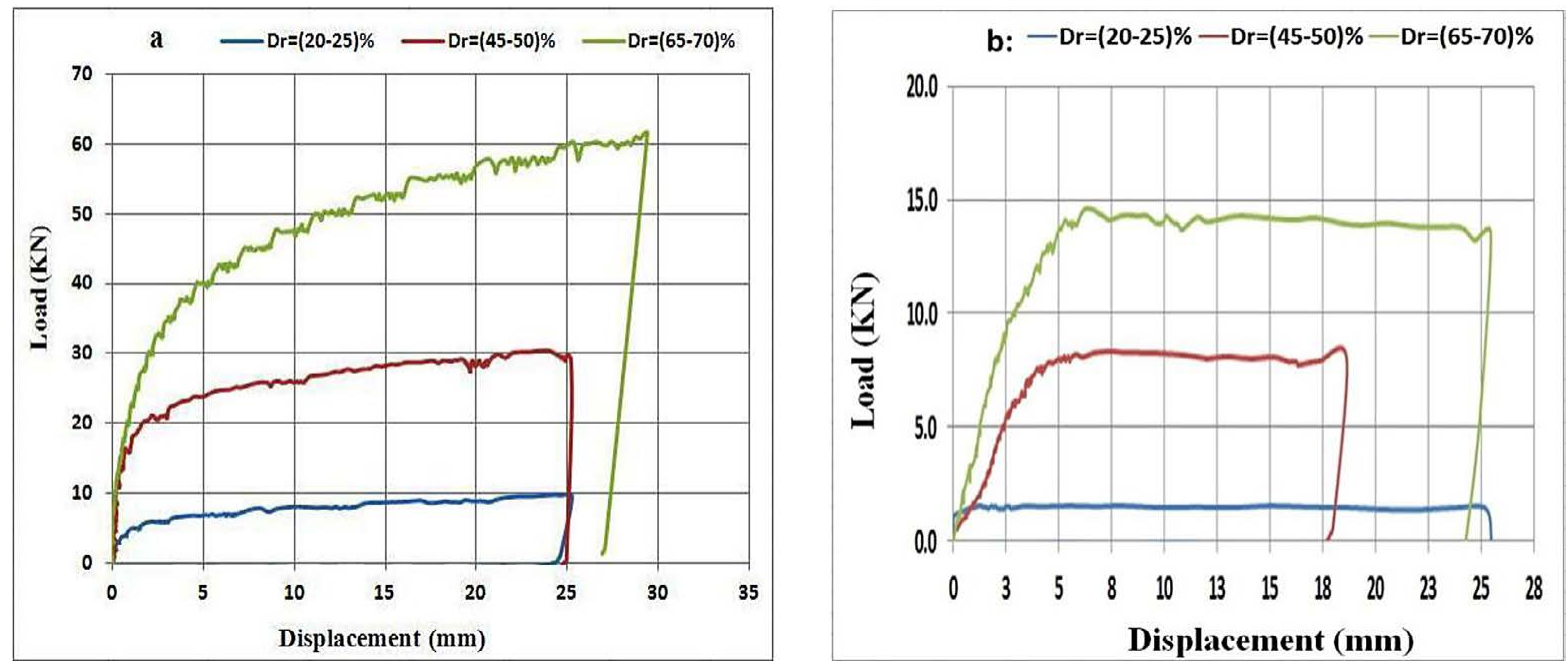

Fig. 9. Load-Displacement curve in open end model piles: left) compression test, right) tension test 

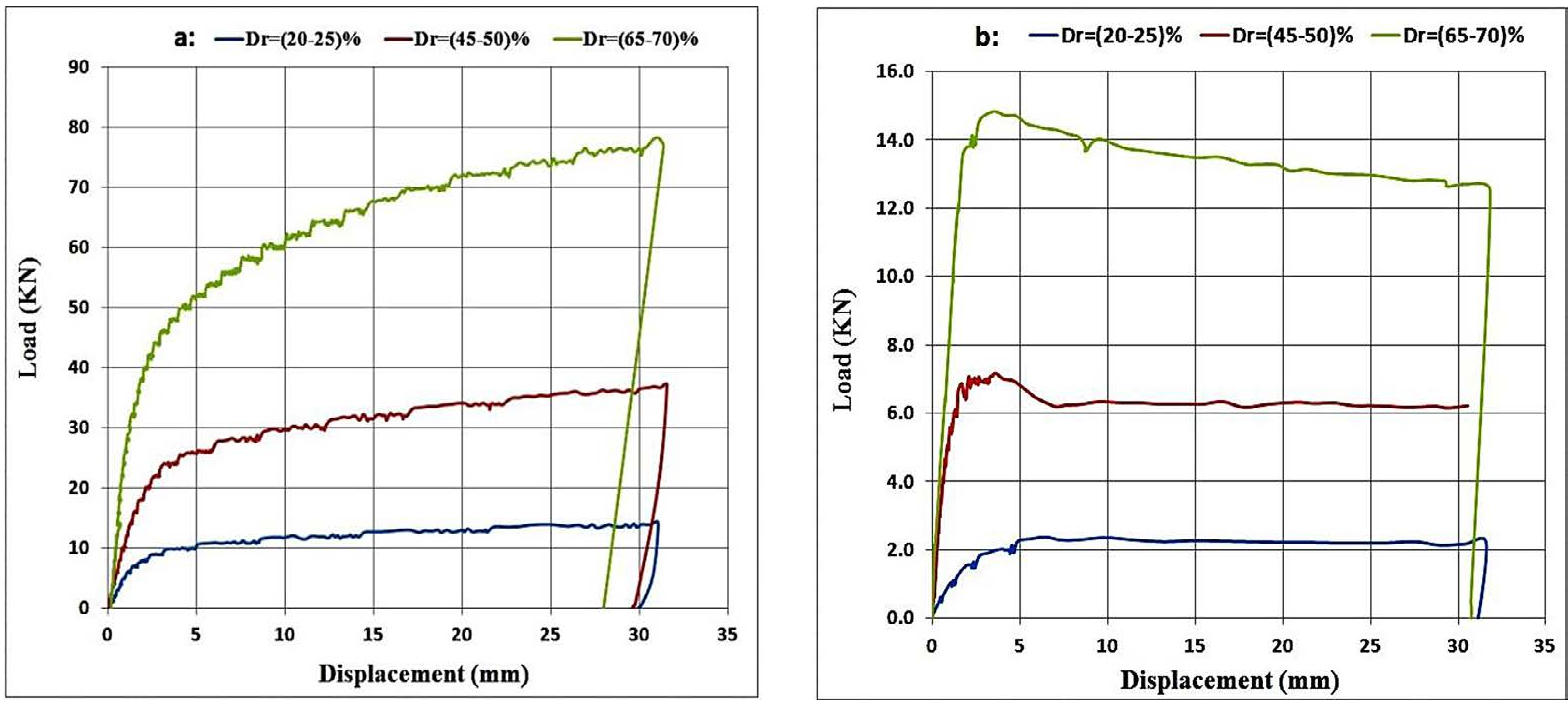

Fig. 10. Load-Displacement curve in close end model piles: left) compression test, right) tension test

capacity as well. The results also illustrate that about $70 \%$ of capacity is obtained before pile displacement exceeds $5 \%$ pile diameter, especially when relative density is over $50 \%$. In displacement equal to $10 \%$ of pile diameter, it will be more than $80 \%$ of ultimate pile capacity. About $90 \%$ of ultimate pile capacity is achieved before the jacking model displacements reach $10 \%$ of pile average diameter. It should be noticed that the uplift capacities are about $25 \%$ of compressive loads.

Thus, in three model piles as mentioned, definition of concerned load with $5 \%$ head pile displacement is a logic decision when relative density is less than about $50 \%$. The displacement will be $10 \%$ of pile diameter while relative density is more than $50 \%$, if movement consideration allows. It is proposed to have a criterion that in these piles the design loads be assumed the loads related to dis- placements of 5\% pile diameter when soil relative density is less than $50 \%$. If not, pile displacement of $10 \%$ pile diameter in compression and $5 \%$ pile diameter in tension is the criterion.

As explained, in loose, medium and dense conditions, the model piles load-displacement behavior is similar, although in loose condition maximum load is obtained in lower pile displacements. Hence, it can be resulted that soil densification is not much effective on pile behavior. In models installed by hammer knocking, bearing increase is upper when relative density varies from medium to dense and in jacking models bearing loads increase more when relative density varies from loose to medium.

Helical pile test results are shown in Table 3. It is observed that a single helix pile with $32 \mathrm{~mm}$ shaft diameter and $64 \mathrm{~mm}$ helix diameter can bear
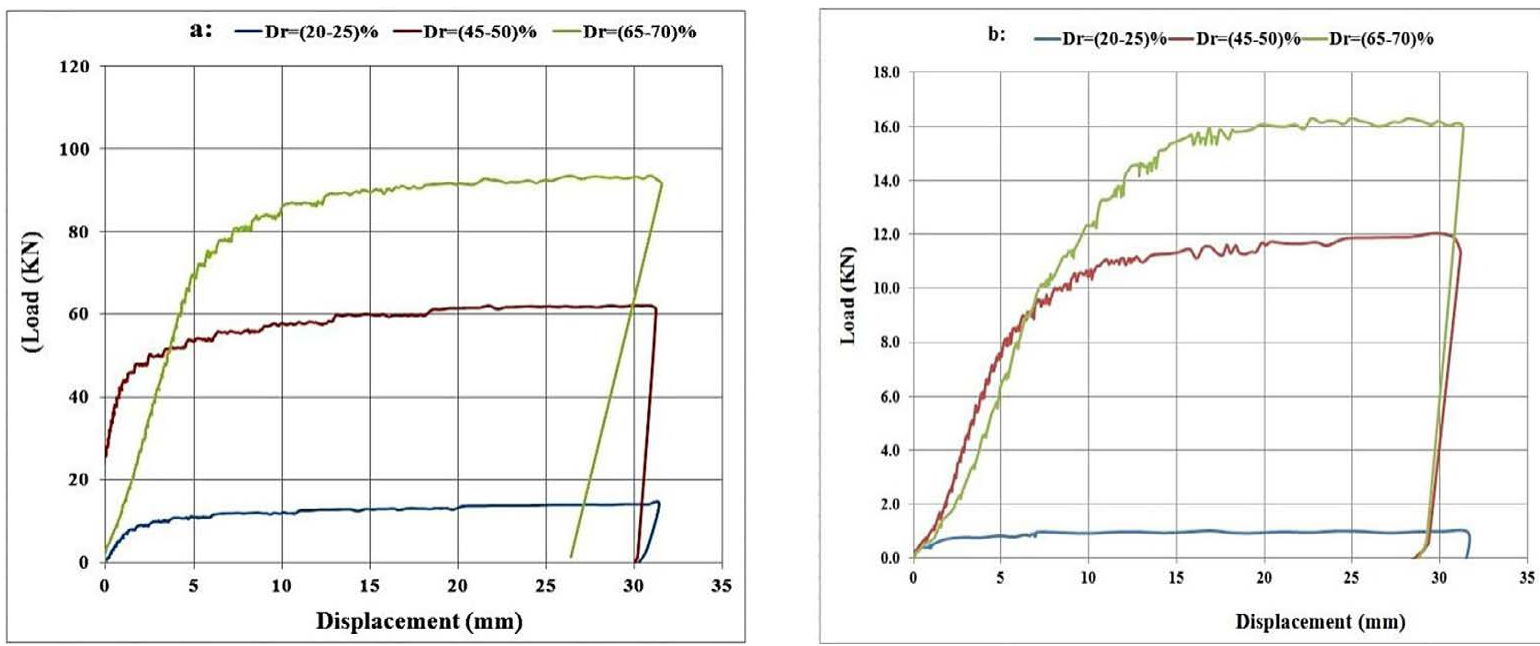

Fig. 11. Load-Displacement curve in Jacking model piles: left) compression test, right) tension test 

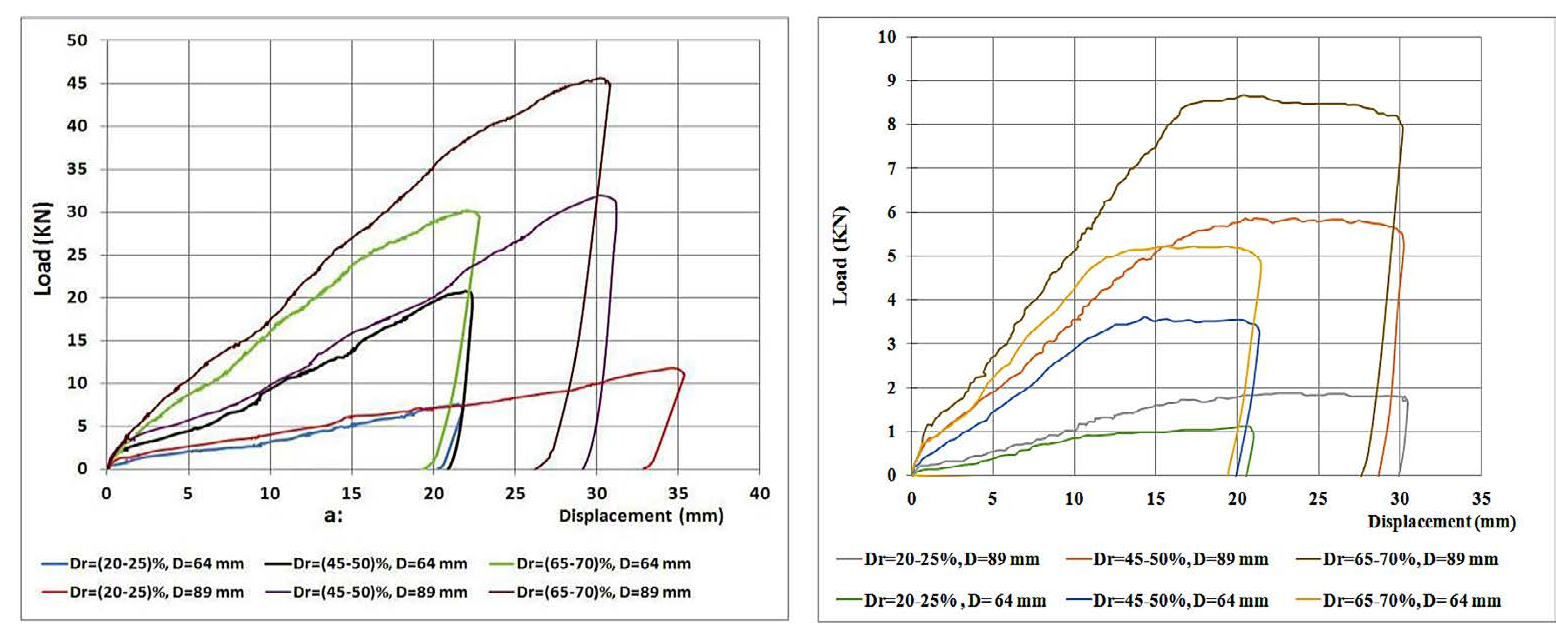

Fig. 12. Load-Displacement curve in single helix pile: left) compression test, right) tension test

3.7 to $15.1 \mathrm{kN}$ compressive load and 0.94 to $4 \mathrm{kN}$ tensile load. If the helix diameter increases to 89 $\mathrm{mm}$, the compressive and tensile loads will raise to 5.5 to $26 \mathrm{kN}$ and 1.4 to $7.3 \mathrm{kN}$, respectively (Fig. 12). So, axial helical capacity increases while helix diameter increases. In this condition the weight of helical pile grows up only by $4 \%$ but compressive and tensile capacities in dense sand increase by about $70 \%$ and $80 \%$, respectively. This increase in loose sand is about $49 \%$ in both compression and tension tests. Therefore, adding helix diameter will be very effective to enhance helical pile capacity and in higher relative density, this can be more pronounced, if the helix materials do not buckle.

If two various sizes of helixes use in one helical pile, better results will be achieved when the larger helix is put on the top. When a helix with $89 \mathrm{~mm}$ diameter is positioned on top of a $64 \mathrm{~mm}$ diameter helix on one helical pile, the compression and tension loads in displacement of $15 \%$ average diameter are about $5 \mathrm{kN}$ to $27 \mathrm{kN}$ and 2 $\mathrm{kN}$ to $10 \mathrm{kN}$ in loose to dense sand, respectively as shown in Fig. 13. If the smaller helix put on the top, these values will vary to $4.1 \mathrm{kN}$ to $23.8 \mathrm{kN}$ in compression and $1.75 \mathrm{kN}$ to $7 \mathrm{kN}$ in tension with the spacing ratio equal to 3 .

According to the results, in double helixes model piles, axial capacity mainly depends on spacing ratio, S/D. So, in this study, helical piles by various spacing ratios were tested. The spacing ratios varied from 1 to 5. Figs. 14 and 15 indicate load-displacement behavior in helical piles with various spacing ratios (S/D) and Fig.

Table 3. Loads in Displacement 15\% of Pile Diameter for Multi Helixes Piles

\begin{tabular}{|c|c|c|c|c|c|c|}
\hline \multicolumn{2}{|c|}{$\mathrm{Dr}=65-70 \%,(\mathrm{kN})$} & \multicolumn{2}{|c|}{$\mathrm{Dr}=45-50 \%,(\mathrm{kN})$} & \multicolumn{2}{|c|}{$\mathrm{Dr}=20-25 \%,(\mathrm{kN})$} & \multirow{2}{*}{ Model numbe } \\
\hline tension & compression & tension & compression & tension & compression & \\
\hline 14.3 & 89 & 11.1 & 60 & 1.5 & 16 & 1 \\
\hline 14 & 65 & 6.2 & 32.5 & 2.2 & 11 & 2 \\
\hline 14 & 50 & 6.9 & 29.1 & 1.3 & 9.4 & 3 \\
\hline 4 & 15.1 & 2.92 & 7.5 & 0.94 & 3.7 & 4 \\
\hline 7.3 & 26.2 & 5.1 & 15.6 & 1.4 & 5.5 & 5 \\
\hline 8.2 & 26.8 & 5.2 & 15.9 & 2 & 4.9 & 6 \\
\hline 11.5 & 33.1 & 6.1 & 18.2 & 3 & 7.5 & 7 \\
\hline 11.9 & 36.8 & 7 & 22.1 & 2.3 & 8.4 & 8 \\
\hline 9.7 & 42.1 & 6.2 & 28.1 & 2 & 10 & 9 \\
\hline- & 40 & - & 25.1 & - & 8.9 & 10 \\
\hline 7 & 23.8 & 4 & 14.2 & 1.75 & 4.1 & 11 \\
\hline 10 & 27 & 5.1 & 15.5 & 2 & 5 & 12 \\
\hline 12.6 & 48.3 & 7.1 & 25.1 & 2.6 & 10.2 & 13 \\
\hline 12.2 & 44 & 6.9 & 28.6 & 2.6 & 10.1 & 14 \\
\hline
\end{tabular}




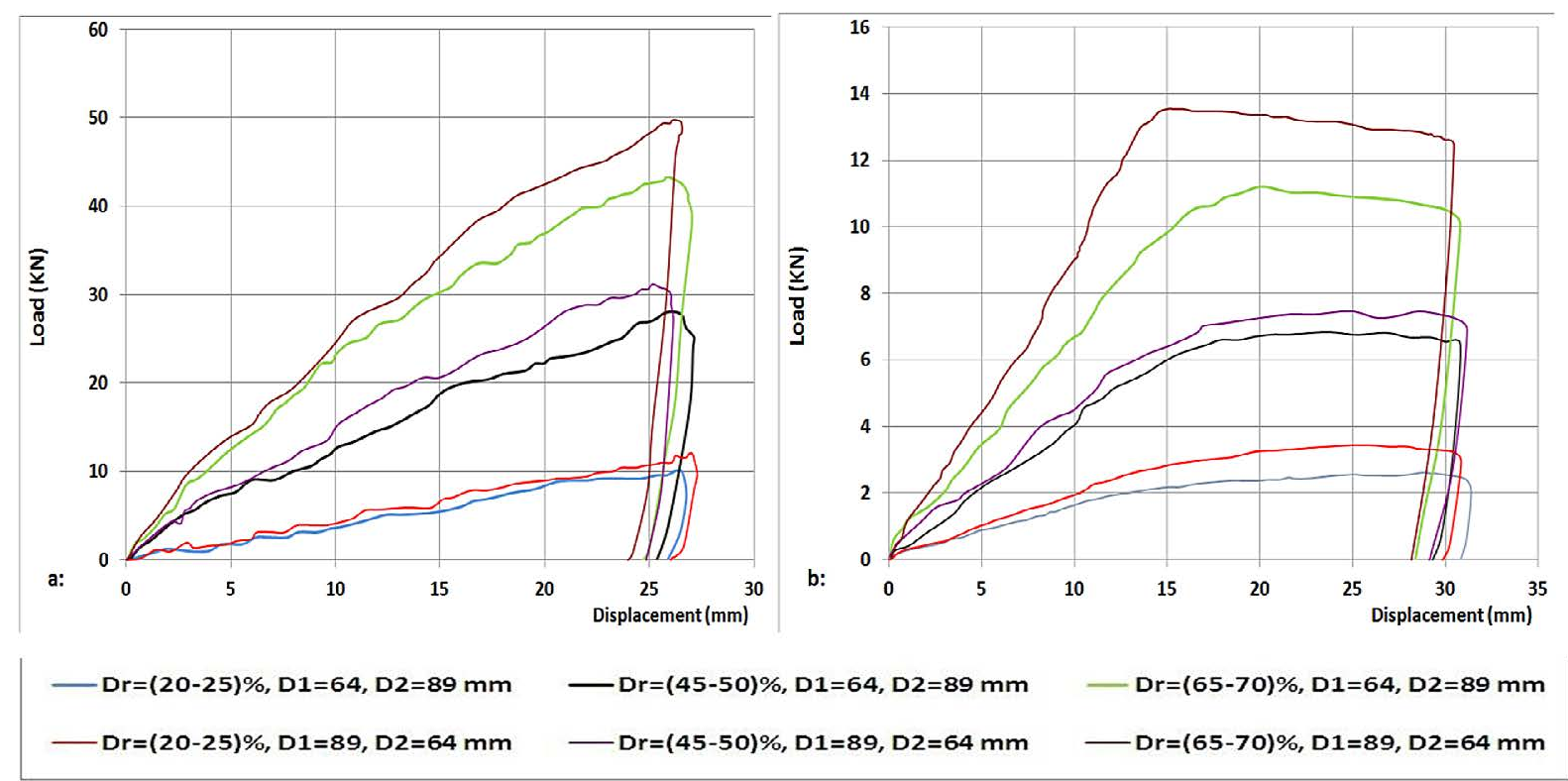

Fig. 13. Load-Displacement curve in double helixes pile (various helixes diameter): left) compression test, right) tension test

16 showed the optimum value of spacing ratio in compression and tension tests which the value of $\mathrm{S} / \mathrm{D}$ equals to 4 and 3 determined respectively. This can be noticed in dense sand helical pile compressive capacity decrease from $42.1 \mathrm{kN}$ to $40 \mathrm{kN}$ when $\mathrm{S} / \mathrm{D}$ increases from 4 to 5 and also in loose and medium conditions. Tensile loads are reduced while S/D varies from 3 to 4 . Loose sand is more sensitive to spacing ratio and reduction is obtained when S/D varies from 2 to 3 . The reason may be more potential of loose soils displacement. Hence, a constraint like of a helix should be positioned in shorter distances. Sakr (2009) and Merifield (2011) had proposed the value of 3 for spacing ratio (S/D) [22] but in this study the results showed that the spacing ratio can be different in compression and tensile loadings. It can differ in loose and dense states, too. Based on FCV-AUT tests the spacing ratio in dense sand and compression state is higher, about 4 , than loose sand and tension state, approximately 3 ,. Consequently, the proposed optimum value of the spacing ratio is designated 4 and 3 for compression and tension loading conditions, respectively.

According to FCV test results in helical piles with three or more helices, a better performance is obtained when the spacing ratio in down is larger than the pile top, i.e. S/D be 2 in top and 3 in down (test N.O. 13) as presented in Figure 17

Experimental study and observations in the field and modeling denote helical piles involve a main difference in comparison with other piles.
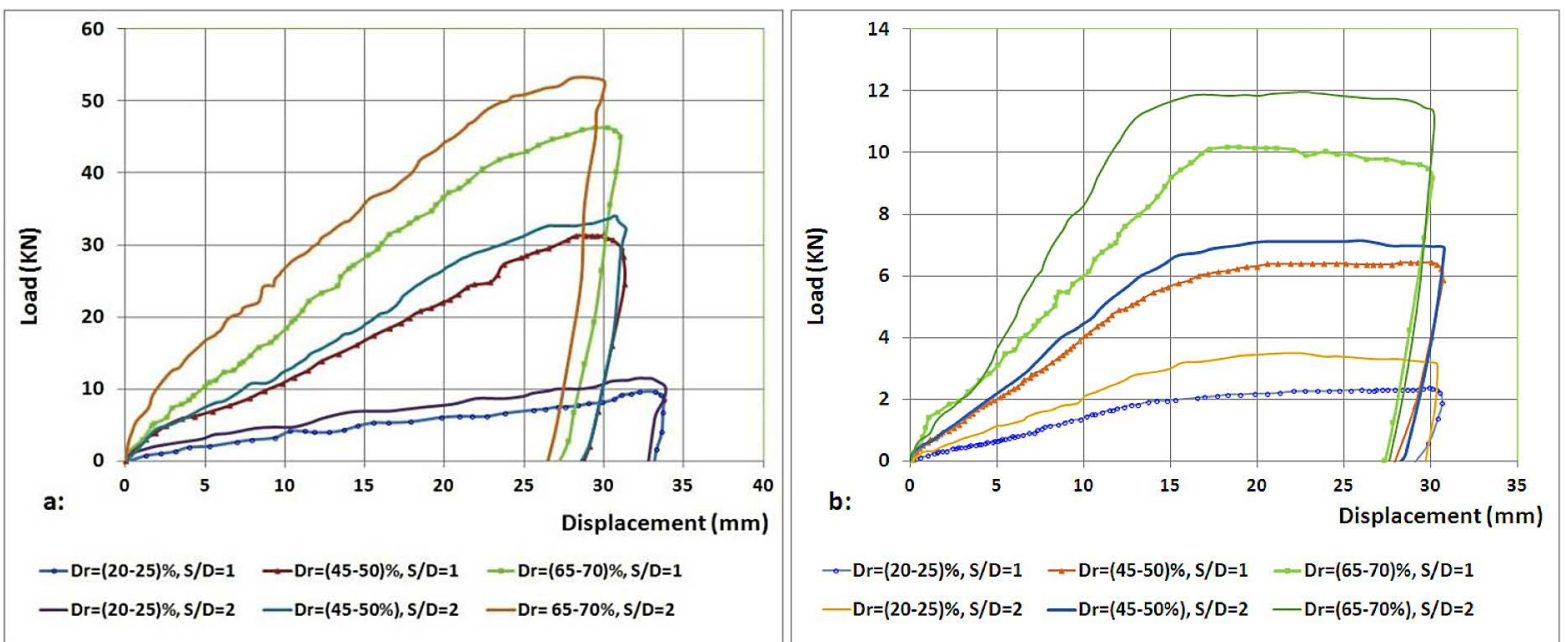

Fig. 14. Load-Displacement curve in double helixes pile (various $S / D$ ): left) compression test, right) tension test 

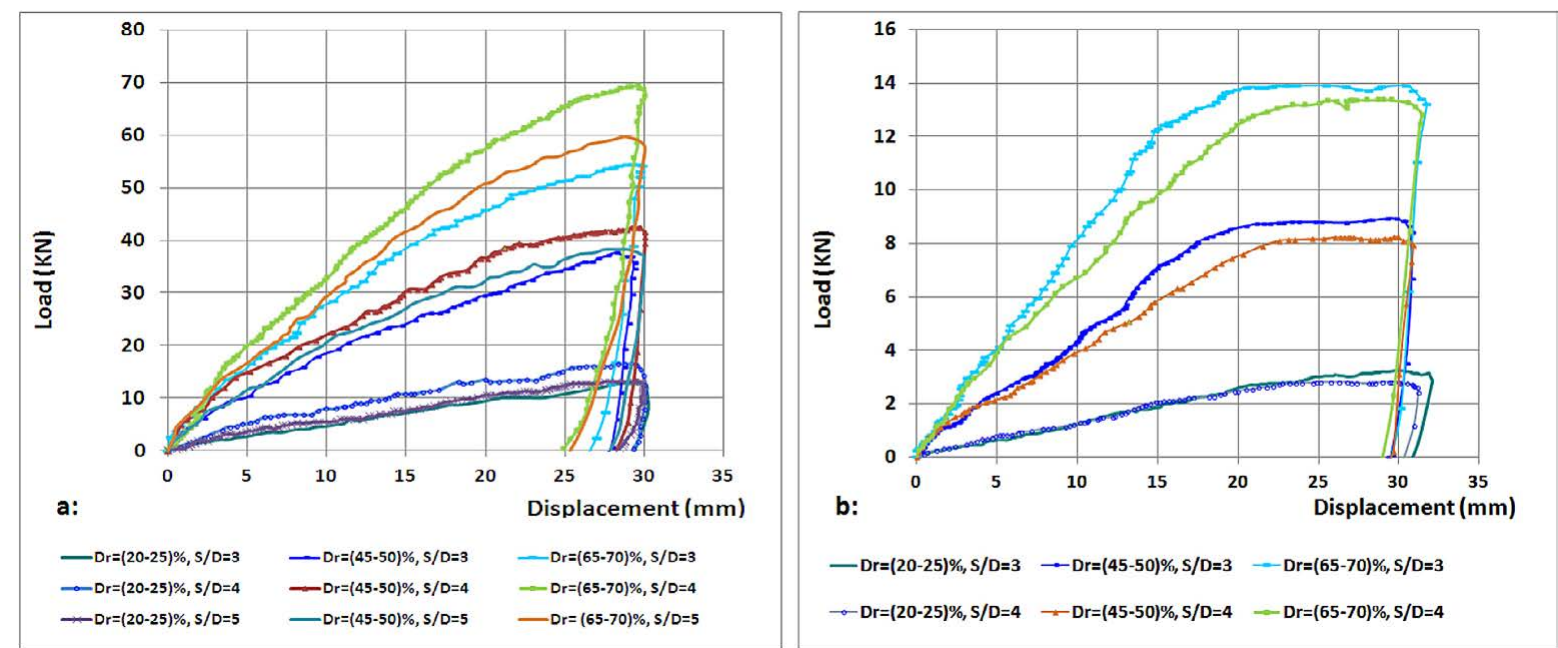

Fig. 15. Load-Displacement curve in double helixes pile (various S/D): left) compression test, right) tension test

Results showed axial capacity in open and closedend model piles installed either hammer knocking or jacking, rises rapidly and in low pile displacements reaches to about $70 \%$ ultimate capacity. Thus, a considerable increase in axial capacities is not expected anymore, when displacements exceed $10 \%$ of pile diameter. In helical piles the axial loads increase versus displacement, progressively. This increase continues till the test ends while displacements up and reach to $30 \%$ pile diameter and no soil failure occurred. In this state further bearing resulted to resist higher loads up to the end of testing. Hence, no plunging failure was observed on helical model piles, tested in FCV-AUT. Therefore, design loads for helical piles can be determined by settlement limitations. Consequently, there are two design load criteria, in ordinary piles it can be the load value concerned to displacement of $5 \%$ of pile diameter in loose and medium state, and 10\% in dense condi- tion. In helical piles, displacement of $15 \%$ of pile diameter is proposed for design loads. It can be limited by structural allowable movements.

Comparing between the load displacements curves for helical piles with single helix and more helixes showed that helical piles have a similar behavior. Hence, the behavior is not dependent to soil densification but helical piles have a better performance in dense sands. The reason might be the higher restraint between sand and helixes. It is important to note the soil should move and have a minimum displacement to occur a proper interlocking in loose conditions. In helical models tensile loads vary from $30 \%$ to $40 \%$ of compressive loads.

FCV test results indicated that helical piles can bear tensile loads almost equal to steel piles with the same diameter of helixes. Comparing pile weights showed that maximum weight of double helixes pile is about $42 \%$ of a usual steel
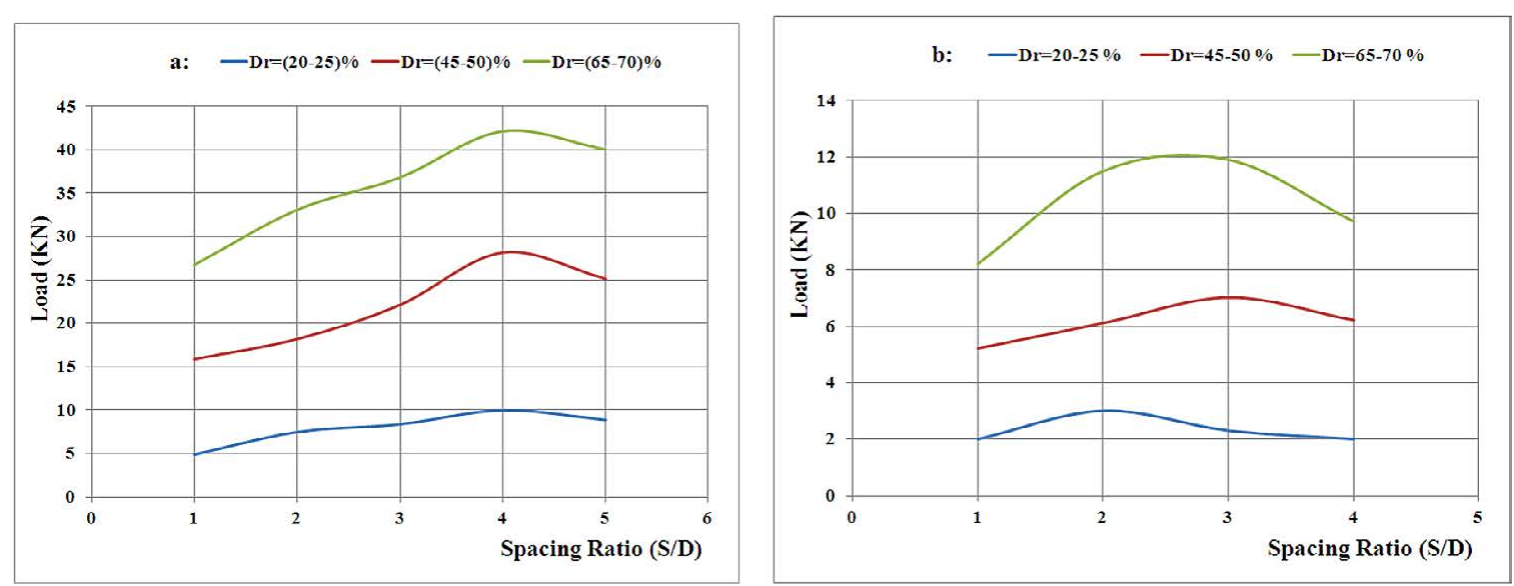

Fig. 16. Comparison in axial pile capacities versus relative Spacing Ratio (S/D): left) compression test, right) tension test (displacement is about $15 \%$ of pile diameter) 

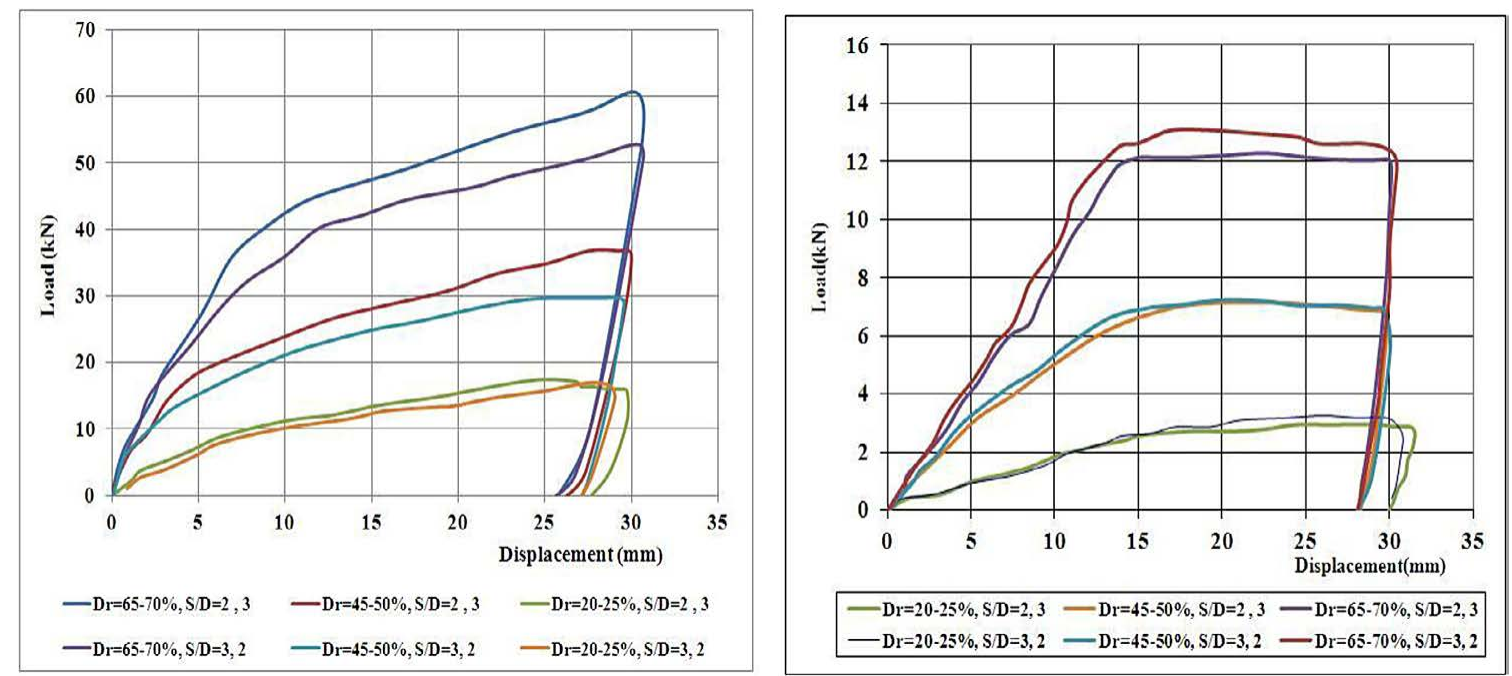

Fig. 17. Load-Displacement curve in three helixes pile (various S/D): left) compression test, right) tension test

pile. Therefore, helical pile is an economic choice to bear uplift loads. Results also revealed that helical pile compressive capacity is about $65 \%$ of a common pile. This provided capability for using them to bear compression loads. According to the present results, in all tests the axial uplift capacity seldom exceeds $40 \%$ of axial compressive capacity. Paying attention to pile size, it is noticed that in model piles the pile embedment depth on diameter ratio (L/D) is about 8.4. Model piles are categorized as short rigid piles, so, the friction resistance which is the most important section to resist reverse uplift loads still is low.

Based on FCV test results, adding a helix to a single helix pile, depending on soil densification and spacing ratio, causing increase tensile capacity about $30 \%$ to $50 \%$. However, maximum rise in compressive capacity is limited to $20 \%$. When three helixes are used, the results show similar behavior to usual piles (without any helixes) as shown in Fig. 16. The results show the larger S/D in lower level of piles is more effective. In both tension and compression states, more increase resulted while relative density increased.

\section{CONCLUSIONS}

Helical piles have some advantages that have made them very reasonable choice for using in offshore structures, building supports and crowded urban sites. Some of these advantages include ease of installation, safety piling because of predrilling elimination, short installation time. Helical piles also are economical and environmentfriendly pile types that the pile applications re- duce carbon dioxide, noise, raw material, fuel and man power.

FCV-AUT is used to test small scale model piles due to its configuration (lateral stresses vary almost linear from zero at the top soil to system applied pressure at the bottom). The FCV device presents a practical and economical alternative to chambers and centrifuge devices. Furthermore, the most limitations associated with simple $1 \mathrm{~g}$ and $\mathrm{CC}$ devices can be eliminated when model piles are tested in FCV. The results of stress tests have shown clearly that FCV can simulate the stress gradient in reality where the full scale piles are instrumented.

According to test results, displacement of $5 \%$ pile diameter in loose and medium, and $10 \%$ in dense conditions are assumed as criteria in usual piles. In helical piles, $15 \%$ of pile diameter is proposed as a criterion if structural movements allow.

Helical piles have a suitable performance to bear tension loads. A helical pile with two helixes can function approximately, equal to a steel pile when the steel pile diameter is the same as the helix diameter. The helical pile weight is less than $45 \%$ of steel pile in these conditions. In compression, helical piles with two helixes can bear about $47 \%$ to $65 \%$ of a common steel pile capacity with the helixes diameter. Therefore, helical piles are reasonable choices in where there are uplift loads, especially in marine projects.

Adding a helix to a single helix pile in tension is more effective than compression loading. Uplift load can be enhanced about 30\% and higher. However, it is limited to $20 \%$ in compression. If two helixes used in one helical pile, have vari- 
ous sizes, better results can be achieved when the larger helix is put on top.

When the number of helixes is up to three, helical piles behavior is closer to common piles behavior. Uplift loads in this state are equal to ordinary piles or more. Compressive loads increment is about $10-15 \%$ in compare with two helixes piles. Helical piles with three or more helixes have a better performance when the spacing ratio in down is larger than the pile top, i.e. $\mathrm{S} / \mathrm{D}$ be 2 in top and 3 in down (test N.O. 13)

Due to the results, helical piles have a better performance when the relative density of site soil increases; this is because of more restraint between soil and pile helixes.

\section{REFERENCES}

1. Basu P. and Prezzi M. 2009. Design and Applications of Drilled Displacement (Screw) Piles. Publication FHWA/IN/JTRP-2009/28., Joint Transportation Research Program, Indiana Department of Transportation and Purdue University, West Lafayette, Indiana, doi: 10.5703/1288284314278.

2. Perko H.A. 2003. Lateral Capacity and Buckling Resistance of Helix Pier Foundations. Foundations Technology Seminar-Helical Foundations and Tiebacks, Deep Foundation Institute, Helical Pile Committee, University of Cincinnati, Cincinnati, $\mathrm{OH}$.

3. Vito D., Cook T. 2011. Case histories on the use of helical piles for retrofitting and new construction. 2011 Pan-Am C-G-S, Geotechnical Conference, Canada.

4. Kurian N.P., Shah S.J. 2009. Studies on the Behavior of Screw Piles by the Finite Element Method. Can. Geotech. J., 46, 627-638.

5. Pack J.S. 2009. Practical Design and Inspection Guide for Helical Piles and Helical Tension Anchors. I.M.R., Inc., Denver, Colorado, Revision 2, U.S.A.

6. Davis R. 2009. The helical pier defined. Web source: http://www.Helicalpierworld.com/archives /hpdefinition.aspx), July 13, 2009.

7. Sakr M., 2011. Installation and Performance Characteristics of High Capacity Helical Piles in Cohesionless Soils. DFI Journal, 5(1), 39-57.

8. Perko H.A. 2009. A Practical Guide to Design and Installation. John Wiley \& Sons, Inc, Hoboken, NJ, USA.

9. Willis D. 2009. How to Design Helical Piles per the 2009 International Building Code. Ram Jack Foundation Solution, USA.

10. Choi Y., Kim D.C., Kim S.S., Nam M.S., Kim T.H. 2013. Implementation of Noise-Free and Vibration-Free PHC Screw Piles on the Basis of Full-Scale Tests. J. Constr. Eng. Manage. 2013.139:960-967.

11. Hoyt R.M., Clemence S.P. 1989. Uplift Capacity of Helical Anchors in Soil. Proceedings of the 12th International Conference on Soil Mechanics and Foundation Engineering, Vol. 2, 1019-1022.

12. Sakr M. 2009. Performance of Helical Piles in Oil Sand. Can. Geotech. J., 46, 1046-1061.

13. Tappenden K., Sego D., Robertson P.: Load Transfer Behavior of Full-Scale Instrumented Screw Anchors. Contemporary Topics in Deep Foundation, ASCE, 2009.

14. Canadian Geotechnical Society, 2006. Canadian Foundation Engineering Manual, CFEM, $4^{\text {th }}$ edition, published in Canada.

15. Sprince A., Pakrastinsh L. 2010. Helical Pile Behavior and Load Transfer Mechanism in Different Soils. Modern Building Materials, Structures and Techniques, The 10th International Conference, pp.1174-1180.

16. Di Bernardo G. 2012. Helical Pile Deck Foundation. New Jersey Deck Boulder, USA.

17. Livneh B., El Naggar M.H. 2008. Axial Testing and Numerical Modeling of Square Shaft Helical Piles under Compressive and Tensile loading. Canadian Geotechnical Journal, Vol. 45, 1142-1155.

18. Sedran G. 1999. Experimental and Analytical Study of a Frustum Confining Vessel. A thesis - submitted to the School of Graduate Studies in Partial Fulfilment of the Requirements for the Degree Doctor of Philosophy, McMaster University, Hamilton, Canada

19. Zare M., Eslami A. 2014. Study of Deep Foundations Performance by Frustum Confining Vessel (FCV). International Journal of Civil Engineering (IJCE), IUST University, Tehran, Iran.

20. Horvath R.G., Stolle D. 1996. Frustum Confining Vessel for Testing Model Piles. Can. Geotech. J., 33, 499-504.

21. Sakr M. 2010. High Capacity Helical Piles - A New Dimension for Bridge Foundations. Proceedings of $8^{\text {th }}$ International Conference on Short and Medium Span Bridges, Niagara Falls, Canada, 2010.

22. Merifield R.S. 2011. Ultimate Uplift Capacity of Multiplate Helical Type Anchors in Clay. Journal of Geotechnical and Geoenviromental Engineering, ASCE, 704-712. 